\title{
THE REPRODUCTIVE CYCLE OF Pleurodema thaul (ANURA, LEPTODACTYLIDAE) IN CENTRAL CHILE.
}

\author{
Helen Díaz-Páez \& Juan Carlos Ortiz
}

Departamento. de Zoología, Casilla 160-C, Universidad de Concepción, Concepción, Chile.

\begin{abstract}
The reproductive cycle of Pleurodema. thaul is described. Males were analyzed according to their spermatogenic stage using histological sections of their testes. For females we used the size and pigmentation of the ovarian follicles. The results show a partially continuous reproductive cycle. Males produce sperm during almost all the year. Spermatogenesis is initiated in summer (FebruaryMarch), when the seminiferous tubules contain abundant undifferentiated spermatozoids, which are transformed to spermatozoa as fall advances (May-June). The first spermatozoa appeared in late May, and spermatogenesis increaces from July to September, sometimes to November. Females present bimodal vitellogenic activity. The first vitellogenic phase is initiated in late February with a progressive maturation of the oocytes, reaching the post-vitellogenic stage between June and August. The breeding period is established during these months and continues until December. In September, some females can begin the vitellogenesis, with a second stage that ends in middle December, when the oocytes that were not spawned, pass massively to the atresic stage. The fat bodies show a synchronic increase with the gametogenic activity in both sexes, that coincide with the greater reproductive activity. Fat bodies are likely to be used as energetic reserve energetic for the vitellogenic activity.
\end{abstract}

Resumen. Se describe el ciclo reproductivo de $P$. thaul. El ciclo de los machos fue analizado según su estado espermatogénico realizando cortes histológicos de testículos. El ciclo de las hembras se analizó de acuerdo a la variación anual de los tamaños y pigmentación de los folículos ováricos. Los resultados muestran un ciclo reproductivo parcialmente continuo. Los machos producen espermatozoides durante casi todo el año. La espermatogénesis se inicia en verano (febrero - marzo), donde los túbulos seminíferos se encuentran con abundantes espermátidas indiferenciadas, que se transforman en espermatozoides a medida que avanza el otoño (mayo - junio). Los primeros espermatozoides son liberados a mediados de mayo. La espermatogénesis se incrementa de julio a septiembre y se puede extender hasta noviembre. Las hembras presentan actividad vitelogénica bimodal. Una primera onda se inicia a fines de febrero con una maduración progresiva de los oocitos, alcanzando el estado post-vitelogénico entre junio y agosto. El periodo de apareamiento se establece entre estos meses y continua hasta diciembre. En septiembre, algunas hembras parecen reiniciar la vitelogénica, con una segunda onda que concluye a mediados de diciembre, cuando los oocitos que no han sido desovados, pasan masivamente al estado atrésico. En ambos casos, los cuerpos grasos muestran un aumento en forma sincrónica con la actividad gametogénica, coincidiendo con el período de mayor actividad reproductiva, por lo que se estima su utilización como reserva energética para la actividad vitelogénica. 


\section{Introduction}

Amphibian populations reflect a close link between environmental variables (temperature, precipitation, photoperiod, altitude, latitude, etc.) and the adjustments of the organisms to their environment (Duellman \& Trueb, 1986; Lofts, 1974). Reproductive patterns are correlated with prevailing climatic conditions. Changes in temperature, and photoperiod stimulate gametogenesis, and establish continuous or discontinuous cycles (Jorgensen, 1972).

Species that inhabit temperate zones, exhibit a determined gonadal annual cycle, with alternation of activity and resting periods, where the reproductive standards reflect the annual climatic cycles (Jorgensen, 1981 and 1984; Jorgensen et al., 1978, Jorgensen et al., 1986; Rastogi al., 1976, Rastogi et al., 1983a). Species that inhabit tropical areas, with a constantly warm and humid climate, exhibit continuous or potentially continuous cycles (Church, 1960; Inger \& Greenber, 1963; Jorgensen et al., 1986; Rastogi et al., 1976).

In Chile, reproductive studies of anura have mainly been centered on their strategies that including parental care of Rhinoderma darwini and R. rufum (Busse, 1991; Jorquera et al., 1981), and on the terrestrial oviparity modalities of species of Batrachyla .(Busse, 1971; Capurro, 1957) and Eupsophus (Formas \& Pugin, 1978; Formas, 1979). However, the spermatogenic and vitellogenic cycles have been practically ignored (Díaz, 1983). There are only a few observations in early studies (Wilhelm, 1927, Cei, 1961, Cei \& Codoceo 1957).

Pleurodema thaul is the most abundant anuran in Chile; its distributional extends from Copiapó

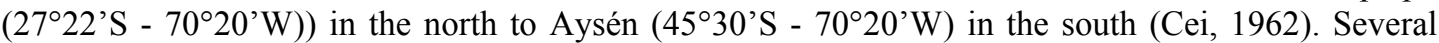
studies have dealt with taxonomic (Victoriano et al., 1995), phylogenetic (Duellman \& Veloso, 1977) and behavioral (Penna \& Solis, 1992; Solis, 1994) aspects of this frog, but little is known about its reproductive biology (Díaz, 1983; Díaz-Páez \& Ortiz, 1996).

Cei (1961), when describing the cycle of Pleurodema bufonina, made reference to a potentially continuous sexual cycle for $P$. thaul, at least in the central and north areas of its distribution, attributing an intensive reproductive activity during the months of September to October in the region of Concepción. In this paper, we describe the reproductive cycle of $P$. thaul. We characterize the vitellogenic and spermiogenic periods, to verify gametic differential activity in both sexes and its relations with environmental conditions (rainfall and temperature).

\section{Materials and Methods}

The reproductive cycle was determined by examining the gonads of 210 individuals of $P$. thaul (143 males and 67 females). Individuals were captured in the vicinity of Concepción, Chile between 1997 and 1998, and were fixed in 10\% formalin, and preserved in 70\% alcohol. Specimens were deposited in the herpetological collection of the Museo de Zoología, Universidad de Concepción (MZUC).

Individuals were measured from snout to vent (SVL) with digital calipers $(0.01 \mathrm{~mm})$ and weighed with a digital scale of $0.01 \mathrm{~g}$. Ovaries, oviducts and fat bodies of females were removed and weighted. The follicles in vitellogenesis were counted and measured with a graduated ocular $(0.001 \mathrm{~mm})$; maturity was determinated by size and pigmentation (Hermosilla et al., 1986; Jorgensen, 1981; Rastogi et al ., 1983b). The number of oocytes was recorded in the different vitellogenesis stages for $20 \%$ of the ovarian weight in each case; we determined the cycle stage by measuring the size and number of 
eggs (Fig. 1). According to this information females were assigned to reproductive categories: ovaries in maturation (stage 5), reproductive ovaries (stage 6), atresic ovaries (stage 7), and ovaries in regression (stage 8) (Ramírez, 1995).

To determine the reproductive stage of males, the testes and fat bodies were extracted. Testes were histologically sectioned $(8 \mu \mathrm{m})$, stained with hematoxiline (Mayer) and stained with $1 \%$ eosine. The recognition of different cellular types in the spermatogenesis was carried out according to Bustos \& Cubillos (1967) and Hermosilla et al. (1983). Ten seminiferous tubules selected randomly from five different sections of each testis were examined (Rastogi et al., 1976). Analyzed samples were assigned to spermiogenic stages following Mayhew \& Wright (1970). The gametic activity of each month is established by the prevail spermiogenic stage in the analyzed samples (Habit \& Ortiz, 1996; Ortiz, 1981).

Information on average montly temperature and rainfall was (Fig. 2) provided by Departmento de Física de la Atmósfera (DEFAO), Facultad de Ciencias Físicas y Matemáticas, Universidad de Concepción. These data were used to describe and relate environmental conditions with reproductive activity. We used ANOVA, and Tukey's test of multiple ranges (Zar, 1984) to analyze annual differences in reproduction. Other statistics used are Kolmogorov-Smirnov Test, ANCOVA, multiple regression, etc.,are described in Dytham (1999).

\section{Results}

\section{Morphometry}

Strong sexual dimorphism exists in body length (SVL female /SVL male $=1.29 ;$ Fig. 3), with females larger than males $(t=16.804 ; \mathrm{p}<0.05 ; 193$ g.l). The SVL of each sex is distributed normally (Kolmogorov-Smirnov Test, $\mathrm{p}>0.01$ ). Sexual maturity in males is reached at $27 \mathrm{~mm}$ evidenced by the presence of sperm in the seminiferous tubules $(\bar{x}=30.48 \mathrm{~mm} \pm 2.92 ; \mathrm{n}=143)$. In females sexual maturity is reached when individuals are more than $31 \mathrm{~mm}(\bar{x}=39.68 \mathrm{~mm} \pm 4.09 ; \mathrm{n}=67)$. The ovaries of smaller females only contain small transparent follicles.

\section{Reproductive cycle of males}

Statistically significant differences in testis size $\left(\mathrm{F}_{11,131} 5.47 ; \mathrm{p}<0.001\right)$ were observed between months. Testis volume increased in fall and reached a maximum in March. Thereafter, only minor small variation exist throughout the year. The monthly analysis of spermatogenic stages (Table 1) indicated reproductively active specimens throughout the year (Fig. 4) with an apparently synchronous testicular activity. Spermiogenic activity seems positively related, although insignificantly, to rainfall and temperature $(\mathrm{r}=-0.35$ and $\mathrm{r}=0.22 ; \mathrm{p}>0.05)$.

During summer (January and February) Stage 4 (Fig. 5a), characterized by the prevalence of undifferentiated spermatozoids, is maintained. As the season advances spermatozoids continue their development until they reach Stage 5 in the fall (March-May). In April, the cellular lumen is formed and the lobes contain cellular nests with secondary spermatozoids and spermatides in development (Fig. 5b). 


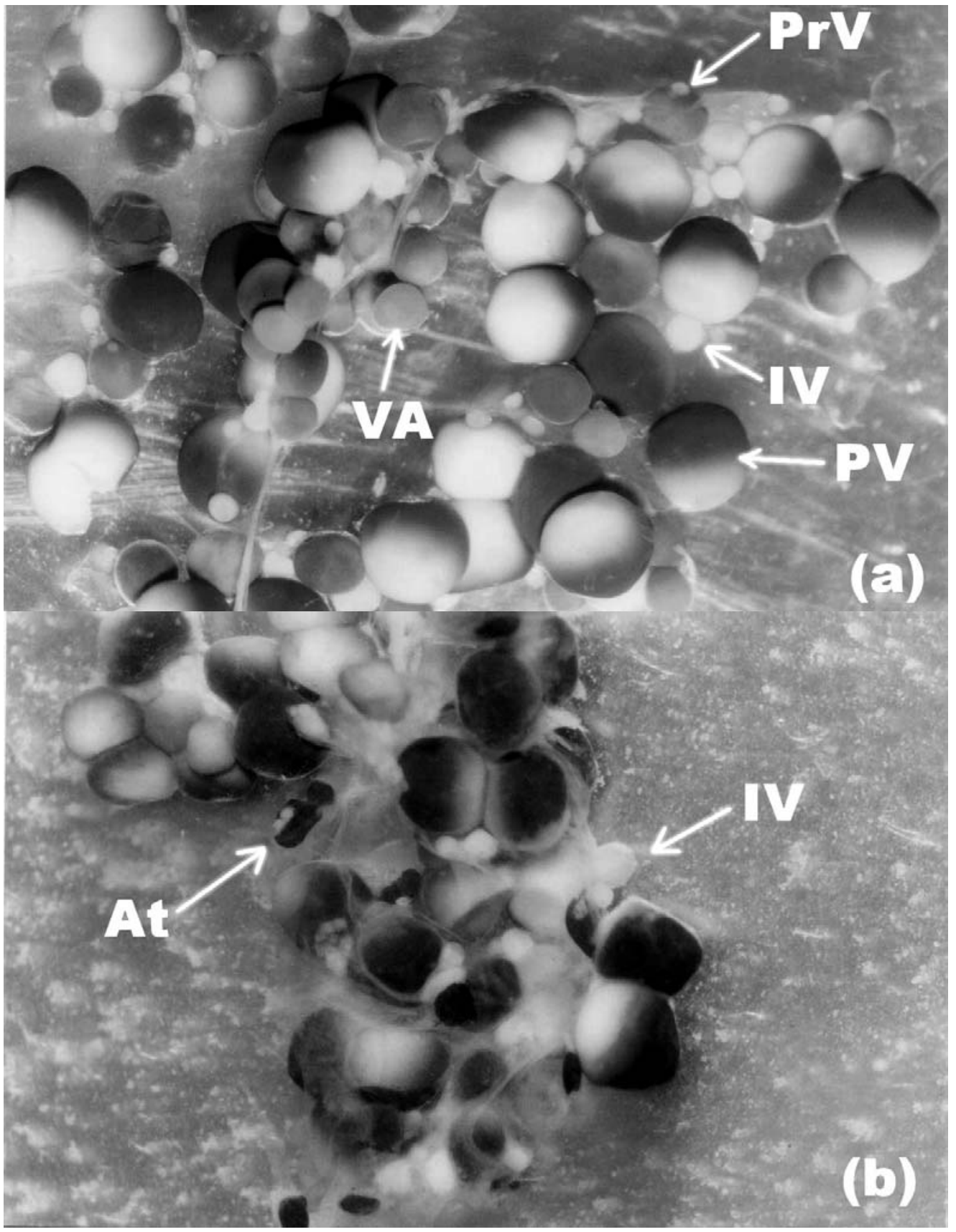

Figure 1: Stages in vitelogenic $P$. thaul. (a) Corresponds to July for a female of $44.94 \mathrm{~mm}$ SVL (A-15x). Previtellogenic oocytes (PrV). Whitish, follicular, almost transparent, with diameter smaller than $0.6 \mathrm{~mm}$; Beginning of vitellogenic (IV), Characterized to be whitish and with diameter of 0.6-1.0 mm; Active vitellogenesis (VA), Dark folliculars, almost black and with average size ranging from 0.9 at $1.7 \mathrm{~mm}$; and postvitellogenic oocytes (PV), in which it is possible to observe the division of both poles, animal and vegetal, and with a size average of 1.6 to $2.0 \mathrm{~mm}$; (b) Female during January of $44.11 \mathrm{~mm}$ (A-10x) with abundant atresic oocytes (At). They are recognized by their intense black color and degeneration features. 

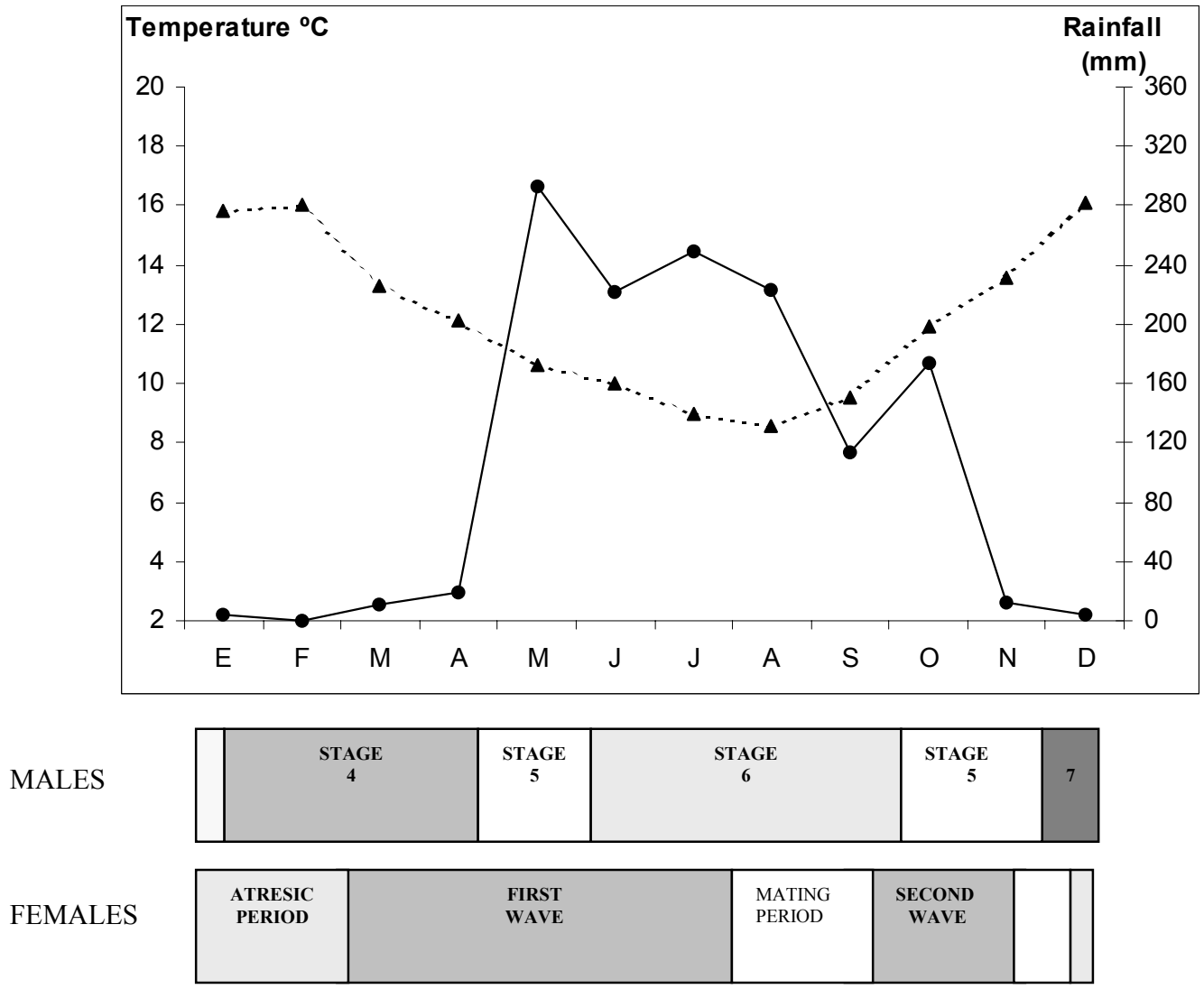

Figure 2.- Ombrotermic diagram of Concepción, in agreement with the reproductive cycle for males and females of $P$. thaul. ( • ) Fluctuation of environmental temperature along the year; ( $\boldsymbol{\Delta})$ Variation of the precipitation per month.

The first sperm are liberated to the tubular lumen during May, when the increase in rainfall favors the increase of the spermiogenesis (Fig. 5c). During June it is still possible to observe specimens in Stage 5 (Fig. 5d), which reach stages 6 and 7 in July (Fig. 6a and 6b) to October (Fig. 6c). In December, a regression of the spermatozoids is occurs. There are numerous spermatides and sperm in clusters within the wetnurse cells (Sertoli cells; Fig. 6b). In addition, a few free sperm also are present in the tubular lumen (Fig. 6d).

\section{Reproductive cycle of females}

The ovaries exhibit significant differences in size throught the year $\left(\mathrm{F}_{11,47} 2.52 ; \mathrm{p}<0.05\right)$. The presence of two main vitellogenic waves was detected. The first wave is initiated in late February when a progressive ripeness of the oocytes contained in the ovaries is evident. The samples from March and April contain few oocytes in an active vitellogenic stage, which mature as fall advances and, reach the post-vitellogenic stage in June -August. 


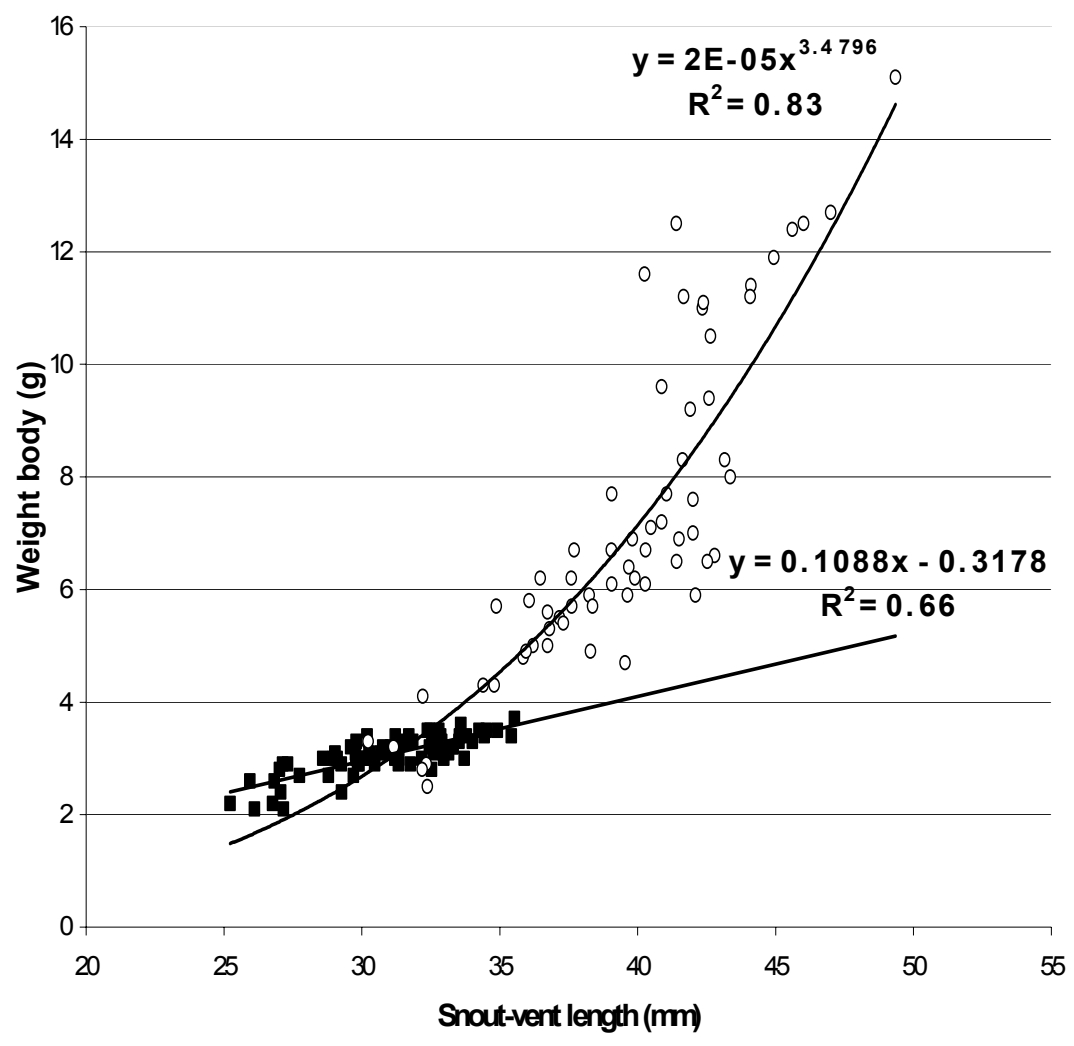

Figure 3.- Relationship of body weight and snouth-vent length in male ( $\boldsymbol{\square})$ and female ( $\bigcirc$ ) of $P$. thaul.

Table 1: Gametogenic stage by month. For male sensu Mayhew \& Wright (1970) and female modificated by Ramirez (1995).

\begin{tabular}{l|cc|cc}
\hline & \multicolumn{2}{|c|}{ Male } & $\mathrm{n}$ & Female \\
MoNTH & $\mathrm{n}$ & Stage & 5 & $7-8$ \\
\hline January & 6 & $3-4$ & 3 & $5-8$ \\
February & 7 & 4 & 3 & $5-8$ \\
March & 6 & $4-5$ & 3 & 5 \\
April & 16 & 5 & 3 & 5 \\
May & 14 & $5-6$ & 10 & $5-6$ \\
June & 10 & 6 & 7 & 6 \\
July & 14 & 6 & 6 & $5-7$ \\
August & 14 & 6 & 6 & $5-7$ \\
September & 8 & $6-7$ & 11 & $5-6$ \\
October & 4 & $5-6$ & 5 & $7-8$ \\
November & 15 & $6-7$ & 5 & 8 \\
December & 7 & $6-7$ & & 5 \\
\hline
\end{tabular}

Apparently, females are asynchronous during the reproductive season. During June, July, August and probably September, some females are post-vitellogenic, whereas others have ripe follicles (Table 1). This pattern seems to indicate two events of gametogenic activity during the reproductive season; this could explain the extension of this first vitellogenic ripeness wave. 


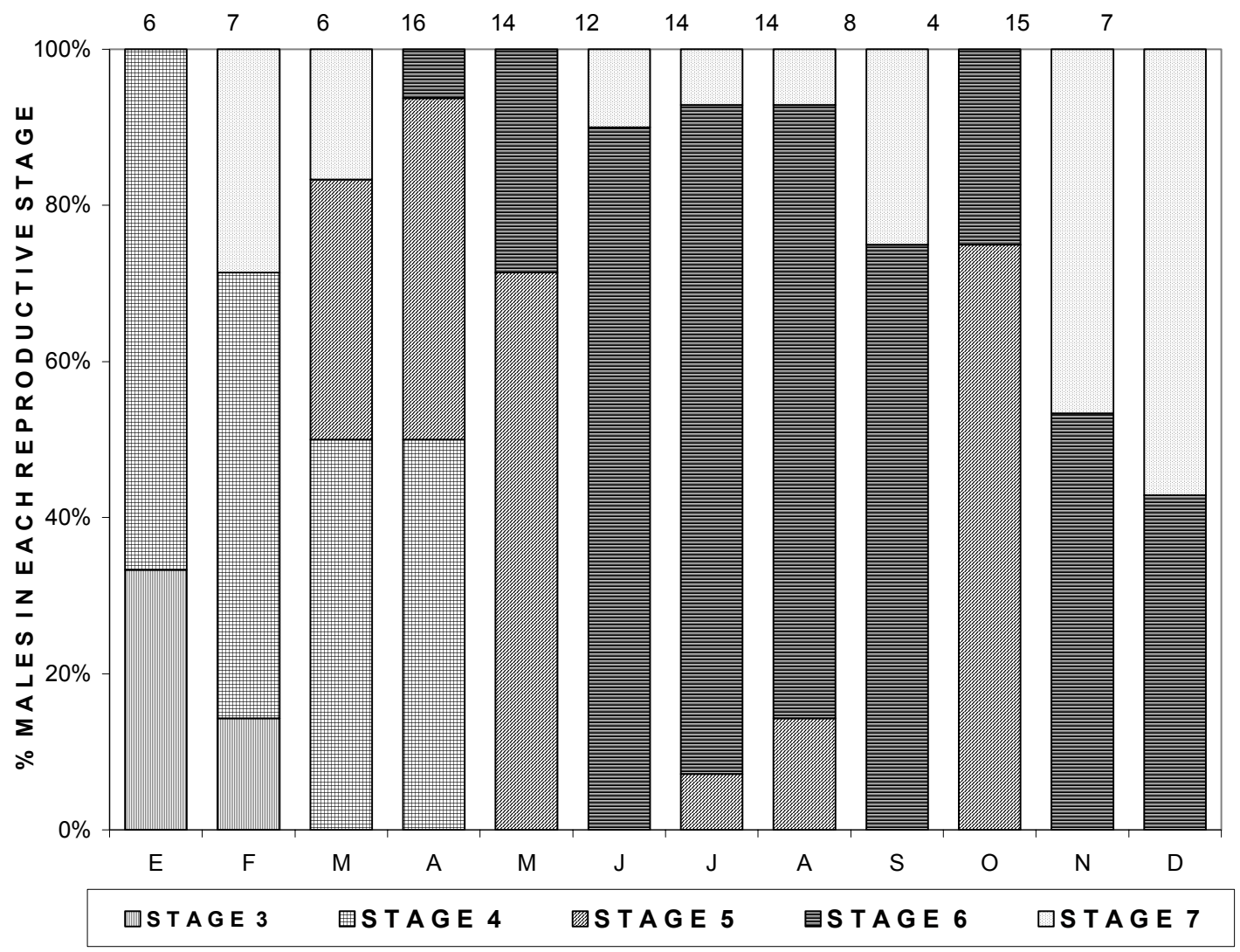

Figure 4.- Percent of males in the different reproductive stages for month. The reproductive stage corresponds to Mayhew \& Wright, 1970 modified. Number over the bar of each month represents sample size.

During September the active vitellogenesis diminishes because most of the oocytes pass to a postvitellogenic stage, and a second shorter vitellogenic wave begins which ends in November and December (Fig. 7). In summer (January-February) the post vitellogenic oocytes that have not been spawned pass to the atresic stage. Renewed vitellogenic activity occurs in late February. A post hoc test (Tukey) of the gonadal mass detected the presence of greater ovarian sizes during January, July, and September coincident with the end of the vitellogenic cycles.

As a result of the high percentage of nonreproductive females during the summer (January-March), as well as the long reproductive season, only data from April to December were used for the environmental analysis. Multiple regression analysis indicated that the increase in vitellogenesis is related to temperature $(\mathrm{r}=-0.66 ; \mathrm{p}<0.05)$ which is the best predictor the vitellogenic activity in gonads $(\mathrm{r}=-0.66 ; \mathrm{p}<0.05 ;)$ as well as in oviducts $(\mathrm{r}=-0.51 ; \mathrm{p}<0.05)$. 


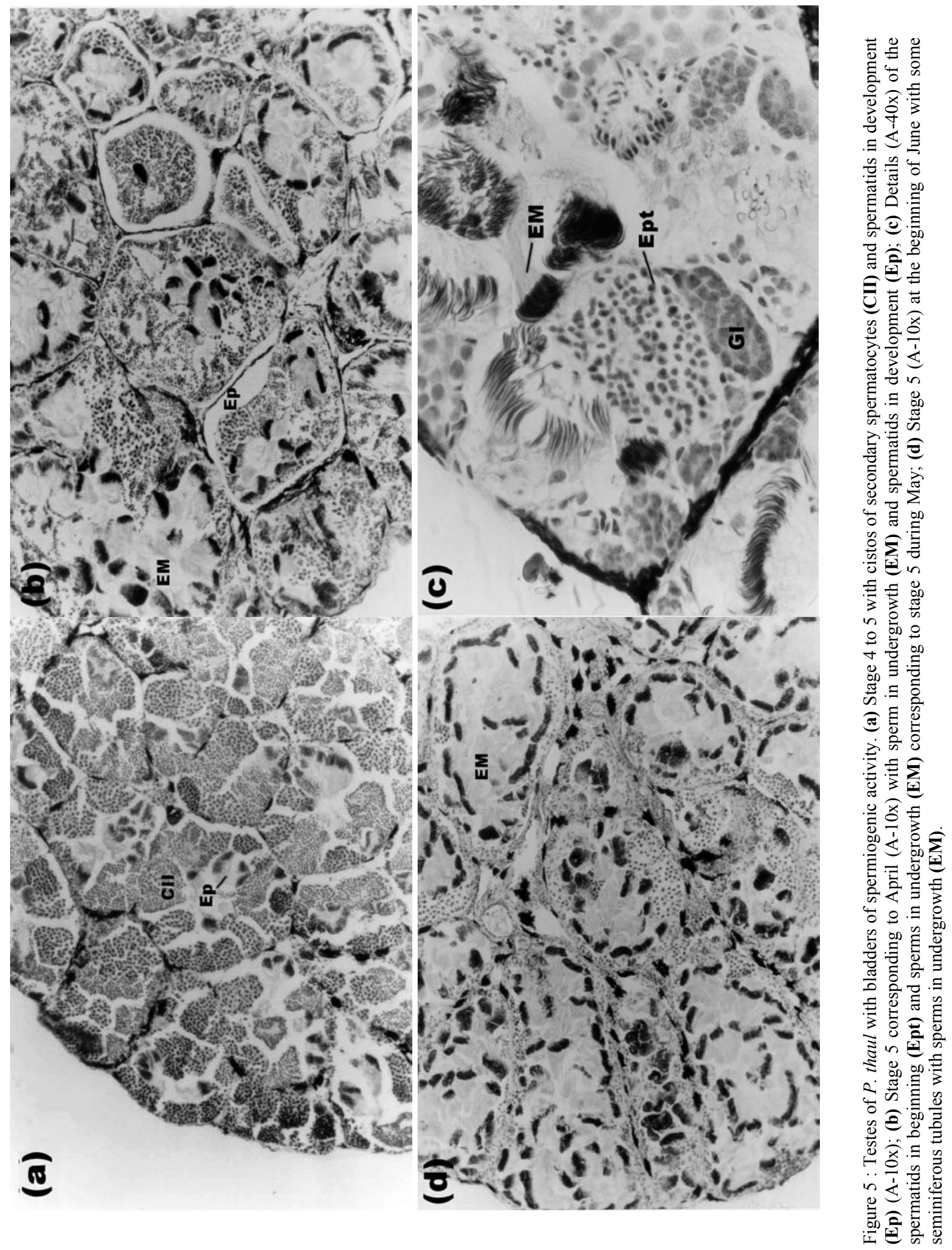




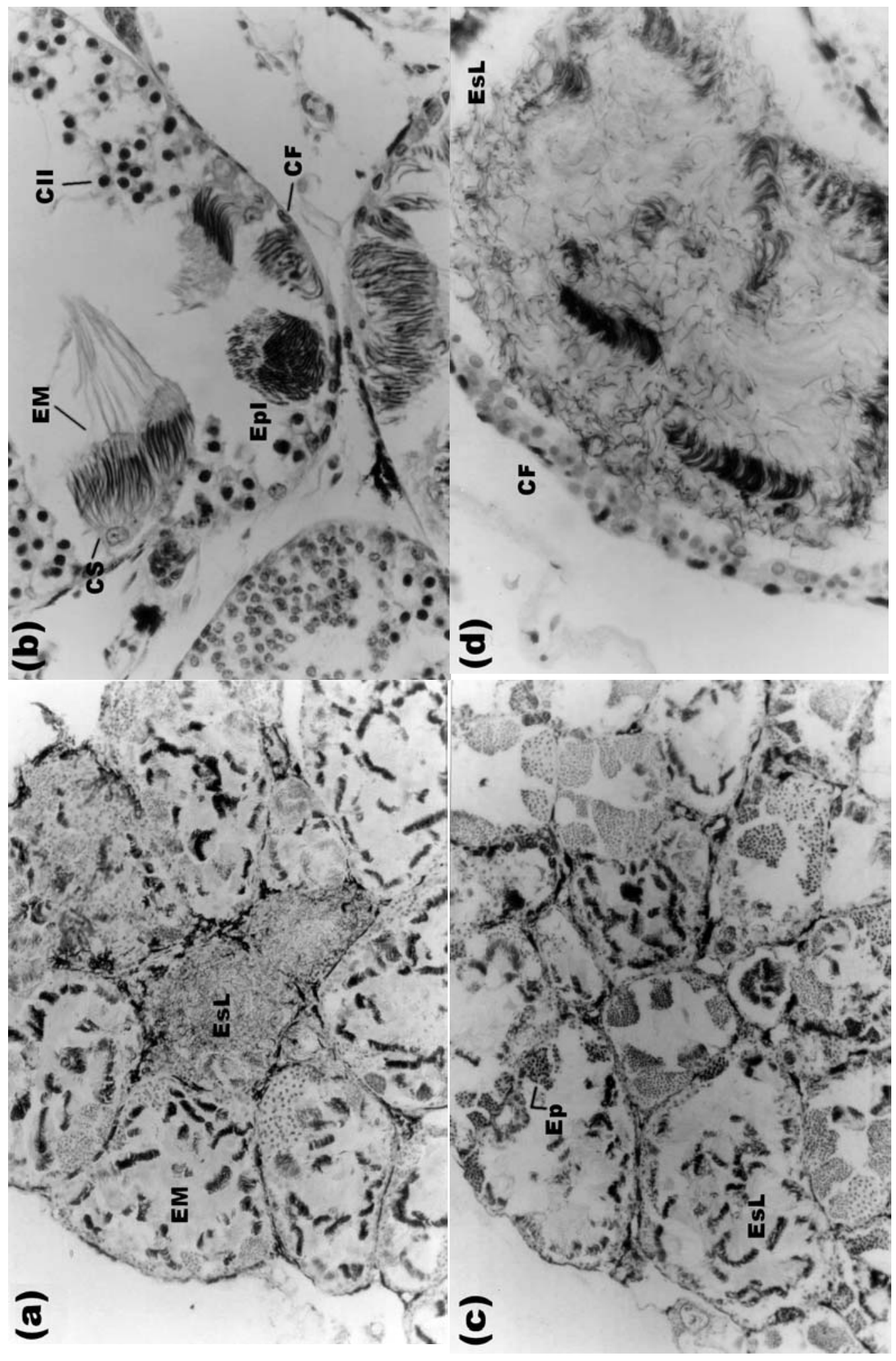

อิธิย

藏寚

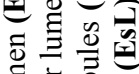

离咅恶

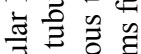

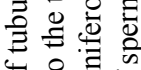

눙요욤

ठृ

幽焉

के : 0

范

$\sum_{0}^{\circ} \stackrel{0}{0}$

될 छ

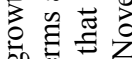

के

$\Xi$ 造:

$\Xi$ 응 흘

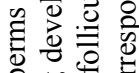

की

司 费

严完导

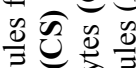

릉 응

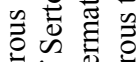

可

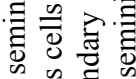

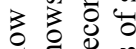

का को

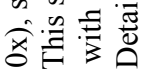

这交总

6000

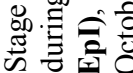

ब

ङ

$\lesssim$ 훙

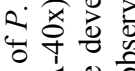

过步

की

๖े

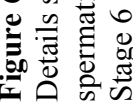




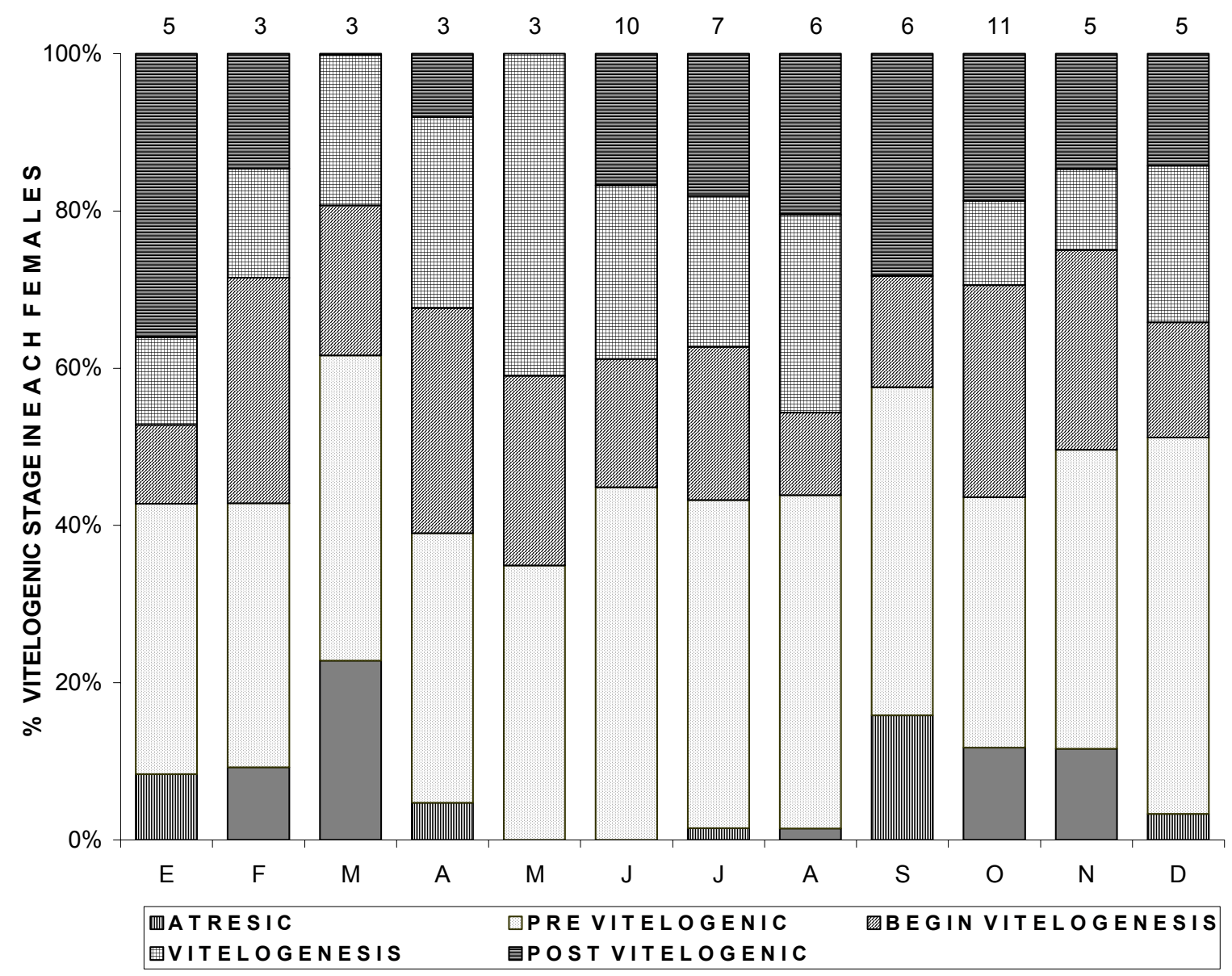

Figure 7.- Percent of the reproductive stage for females per month. The reproductive stage corresponds to Rastogi et al., 1983 and Hermosilla et al., 1986 modified. Number over the bar of each month represents sample size.

\section{Cycle of fat bodies}

The cycle of fat male and female bodies is shown in figure 8. One way covariance analysis (ANCOVA) revealed that fat bodies of males are not significantly affected by variation in body size $\left(\mathrm{F}_{11,130}=1.60 ; \mathrm{p}>0.05\right)$, but there was significant variation of fat bodies within each month $\left(\mathrm{F}_{11,52}=\right.$ $2.92 ; \mathrm{p}<0.05)$.

In males, fat bodies increase as the spermiogenic activity passes to Stages 5 and 6 (Fig. 8). The greatest proportion was observed during June, July and September, a period described as the highest reproductive activity for the species (Cei, 1961; 1962). In females, the total average mass of the bodies was significantly greater in the vitellogenic individuals than in gravid and nonreproductive individuals $(\mathrm{p}<0.05)$. Likely, the fat bodies increase in the periods previous to vitellogenesis, with greater proportions in March and June (Fig. 8). In both sexes, the increase of fat bodies is positively related with temperature $(\mathrm{r}=-0.61 ; \mathrm{p}<0.05$ and $\mathrm{r}=0.50 ; \mathrm{p}<0.05)$, but not with rainfall $(\mathrm{r}=0.50$ and $\mathrm{r}=0.44 ; \mathrm{p}>0.05)$. 

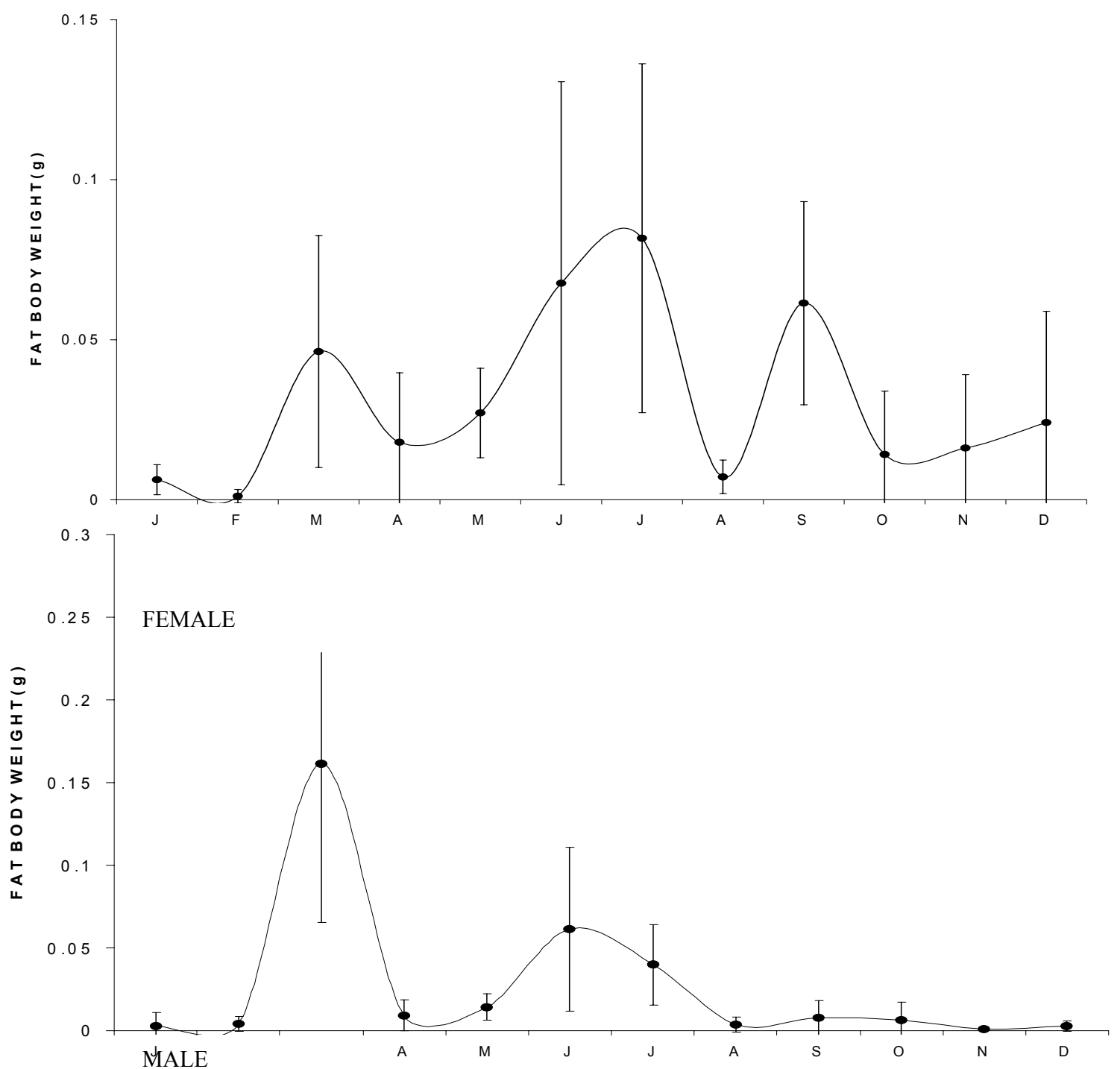

Figure 8.- Monthly changes in fat body weights for male and female $P$. thaul. Data presented as adjusted mean \pm SE.

\section{Discussion}

The reproductive cycle of Pleurodema thaul is almost continuous, with gametogenic activity in males and females during fall, winter, and spring, and a recession during the summer. Both sexes seen to be influenced by environmental conditions (Duellman \& Trueb 1986, Wake, 1995).

The decrease in temperature activated the spermiogenic process in $P$. thaul. Jorgensen \& Billeter (1982) indicated that the annual temperature cycle is the main factor in the synchronization of the spermatogenic wave in testes of frogs and toads from the temperate zone. The data indicates that although spermatogenesis is maintained throughout the year, only one subset of spermatozoids mature coincidentally with the reproductive cycle of females (Wake, 1995).

This pattern is found in temperate zone amphibians (Jorgensen, 1992), where the plasticity of the ovarian c. FEMALE l., 1983b) is the response to a variable and unpredictable environment 
(Ritke \& Lessman, 1994). The changes in the ovary are mainly due to fluctuations of environmental factors: temperature and rainfall (Duellman \& Trueb, 1986; Jorgensen, 1992). The ovary increases its weigh as the environmental temperature decreases. The positive relation between ovarian mass and total corporal mass, is altered during the reproductive season and the subsequent summer (Jorgensen, 1981, 1986 and 1992; Rastogi et al., 1983b).

The female reproductive cycle consists of two principal vitellogenic waves, one at the beginning of the fall, and the second around late winter. Recruitment of follicles is produced after each ovulation wave; the new follicles undergo a vitellogenic maturation process, but there is only evidence that those of the first wave are expelled. The timing coincides with the increase of fat bodies doing these dates (Fig. 8), which would be used as energetic reserve to initiate vitellogenesis (Rastogi et al., 1983b).

It is likely that there are two oviposition strategies in a season, when some females do not enter in to quiescence after the first oviposition and retain mature oocytes to be used in a following ovoposition (Van Beurden 1979). This would facilitate multiple ovoposition during the reproductive season (Jorgensen, 1992, Ritke \& Lessman, 1994) and would explain the presence of mature females between September and December. Thus, females that enter early into vitellogenesis would have a second vitellogenic period around late winter (September). They would exhibit two vitellogenic cycles per season, one at the beginning of winter with oviposition in June, and the second in late spring with oviposition in November and December.

The inverse relations between fat bodies and gonadal development has been observed in several species of amphibians from temperate zones (Jorgensen et al., 1979; Jorgensen, 1992). The weight of fat bodies varies according to annual temperature and food availability (Church, 1960; Frost, 1983; Jorgensen, 1986), but the role of these factors in gametogenesis is not clear (Saidapur \& Hoque, 1996).

The cycle of fat bodies of males and female $P$. thaul coincides with greater activity periods. In males, the increase of fat bodies is initially simultaneous with the increase in testis volume. The gonadal function in males is less dependent of nutritional condition than in females, suggesting that fat bodies act only in the reduction of the gonadotropic secretion rate decreasing the spermatogenic activity when they are scarce (Guba et al., 1989; Jorgensen, 1992). It is likely than in males fat bodies only serve for the production supported by their coincidental with spermiogenic activity toward Stages 5 and 6 (Fig. 8). The larger fat bodies at the beginning of winter (June, July and September) are coincident with the period greater activity for $P$. thaul (Cei, 1961; 1962).

In females the decrease of fat bodies in April would be in agreement with a decrease of the oocytes of vitellogenesis initiation and the increase in the post-vitellogenic oocytes, as part of the vitellogenic kinetic. Likely, fat bodies exhibit their minimum size during the spawning period (Verrel et al., 1986) and decrease progressively while the size of oocytes increases (Frost, 1983, Jorgensen, 1992). The nutritional condition of females is an important factor in their reproductive success (Jorgensen, 1986). Therefore, they depend on the contribution to vitellogenesis by fat bodies. Based on these precedents, it seems worthy an action of the fat bodies as a support in the growth of the oocytes, without being an obligatory role (Frost, 1983, Saidapur \& Hoque, 1996). The fat bodies reduce in size and even dissappear during the reproductive season, because they have been used as energy source to clutch the first posture of the season (Ritke \& Lessman, 1994).

The cycle described for $P$. thaul coincides with that outlined for amphibians that inhabit temperate zones, with potentially continuous spermiogenic and vitellogenic cycles. These cycles include a negative relation between fat bodies and gametic activity (Morton, 1981; Jorgensen, 1992).

There are also documented cases in which one species exhibits different reproductive periods according to climatic conditions (Díaz et al., 1987). Therefore, we suggest that continous gametogenic activity regulated by environmental conditions may be the general pattern in Chilean amphibians. As in other species of temperate regions, such as Rana esculenta (Rastogi et al., 1976), changes in temperature are the main influence on reproction followed by changes in rainfall (Fig. 2). Thus, the 
breeding period commences when temperature decreases and precipitation increases. To further inderstand the organics of the reproductive cycle, more research on hormonal control is needed.

Acknowledgments. This work was funded by a grant FONDECYT 89/ 1199 and Universidad de Concepción D.I.U.C. 92.38.28-1. To Carlos Galindo-Leal (Stanford University) and Ramón Formas (Universidad Austral de Chile) for criticism and suggestions to an earlier manuscript and two anonymous referees made useful comments on the manuscript. This work was partially conducted during the graduate program of H.D-P., who acknowledges a doctoral fellowship awarded by Universidad de Concepción.

\section{REFERENCES}

Busse, K. 1971. Desarrollo de Batrachyla leptopus Bell con observaciones sobre su ecología y comportamiento (Amphibia, Leptodactylidae). Inv. Zool. Chil. 15:5-64.

Busse, K. 1991. Bemerkungen zum fortpflanzungsverhalten und zur Zucht von Rhinoderma darwinii. Herpetofauna 13(71): 11-21.

Bustos, E. \& M., Cubillos. 1967. Ciclo celular en la espermatogénesis de Bufo spinulosus Wiegmann, estudio radioautográfico preliminar. Biológica 40: 62-71.

Capurro, L. 1957.Anfibios de la región de los Lagos Valdivianos. Inv. Zool. Chil. 4: 22-29.

Cei, J.M. 1961. Pleurodema bufonina Bell, anfibio australe con ciclo espermatogénico discontinuo autoregolato. Arch. Zool. Italiano 46: 167-180.

Cei, J.M. 1962. Batracios de Chile. Ediciones Universidad de Chile: 128pp. + cviii Plates.

Cei, J.M. \& M., Codoceo. 1957. Probable discontinuidad del ciclo espermatogénico de Pleurodema bufonina. Inv. Zool. Chil. 4: 77-82.

Church, G. 1960. Annual and lunar periodicity in the sexual cycle of the Javanese toad, Bufo melanostictus Schneider. Zoologica 45: 181-188.

Díaz, N. 1983. Bibliografía sobre anuros chilenos 1962-1982. resúmenes y comentarios. Medio Ambiente 6(2): 80-98.

Díaz, N., Sallaberry, M. \& J., Valencia. 1987. Microhabitat and reproductive traits in populations of the frog Batrachyla taeniata. J. Herpetol. 21(4): 317-323.

Díaz- Páez, H. \& J.C., Ortiz. 1996. Descripción y Análisis de los aspectos reproductivos en los anfibios Chilenos (Resumen). IV Congreso Latinoamericano de Herpetología, Santiago, Chile.

Duellman, W. \& L., Trueb. 1986. Biology of amphibians. Mc Graw-Hill Company. New York, U.S.A.

Duellman, W \& A., Veloso. 1977. Phylogeny of Pleurodema thaul (Anura: Leptodactylidae): A Biogeographic model. Univ. Kansas Mus. Nat. Hist. Occas. Pap. (64): 1-46.

Dytham, C. 1999 Choosing and using statistics: a biologist's guide. Blackwell Science. U. K.

Formas, R. 1979. La herpetofauna de los bosques temperados. In: W. E. Duellman (ed.). The South American Herpetofauna: Its Origin, Evolution and Dispersal. Mus. Nat. Hist. Univ. Kansas. Monograph. 7: 341-369.

Formas, R. \& F., Pugin. 1978. The tadpole of Hylorina sylvatica, Eupsophus vittatus and Bufo rubropunctatum in southern Chile. Herpetologica 34(4): 355-358.

rost, J. 1983. Comparative feeding and breeding strategies of a sympatric pair of leopard frogs (Rana pipiens Complex). J. Exp. Zool. 225: 135-140. 
Guha, K.K., Jorgensen, C.B. \& L.O., Larsen. 1980. Relationship between nutritional state and testis function, together with observations on patterns of feeding, in the toad, Bufo bufo bufo. J. Zool. (London) 192: 147-155.

Habit, E. \& J.C., Ortiz. 1996. Ciclo reproductivo de Phymaturus flagellifer (reptilia, Tropiduridae). Bol. Soc. Biol. Concepción 67: 7-14.

Hermosilla, I., Urbina, A. \& J., Cabrera. 1983. Espermatogénesis en la Rana Chilena Caudiverbera caudiverbera (Linne, 1758) (Anura, Leptodactylidae). Bol. Soc. Biol. Concepción 54: 103-115.

Hermosilla, I., Coloma, L., Weigert, G., Reyes, E. \& V., Gomez. 1986. Caracterización del ovario de la "Rana Chilena" Caudiverbera caudiverbera (Linne, 1758) (Anura Leptodactylidae). Bol. Soc. Biol. Concepción 57: 37-47.

Inger, R.F. \& B., Greenberg. 1963. The annual reproductive pattern of the frog Rana erythraea in Sarawak. Phisiol. Zool. 36: 21-33.

Jorgensen, C.B. 1981. Ovarian cycle in a temperate zone frog, Rana temporaria, with special reference to factors determining number and size of eggs. J. Zool. (London) 195: 449-458.

Jorgensen, C.B. 1984. Relation between hibernation and ovarian functions in a temperate zone frog, Rana temporaria. Acta Zoologica 65: 239-247.

Jorgensen, C.B. 1986. External and internal control of patterns of feeding, growth and gonadal function in a temperate zone anuran, the toad Bufo bufo. J. Zool. (London) 216: 211-241.

Jorgensen, C.B. 1992. Growth and reproduction., p. 439-466. In: Environmental physiology of the amphibians. M.E. Feder and W.W. Burggren (eds.). Univ. Of Chicago Press, Chicago, Illinois.

Jorgensen, C.B.. \& E., Billeter. 1982. Growth, differentiation and function of the testis in the toad Bufo bufo bufo (L.) with special reference regulatory capacities: Effects of unilateral castration, hyphophysectomy, and excision of Bidder's organs. J. Exp. Zool. 221: 225-236.

Jorgensen, C.B., Hede, K.E. \& L.O., Larsen. 1978. Environmental control of annual ovarian cycle in the toads Bufo bufo bufo L.: Role of temperature. In: Environmental endocrinology, p. 28-36. I. Assenmacher and D.S. Farner (eds.), Springer-Verlag. Berlin.

Jorgensen, C.B., Larsen, L.O. \& B., Lofts. 1979. Annual cycles of fat bodies and gonads in the toad Bufo bufo (L.), compared with cycles in other temperate zone anurans. Det Kongeliege Danske VidensKabernes Selskab Biologiske Skrifter 22: 1-37.

Jorgensen, C.B., Shakuntala, K. \& M., Vijayakumar. 1986. Body, reproduction and growth in a tropical toad, Bufo melanostictus, with a comparison of ovarian cycles in tropical and temperate zone anurans. Oikos 46: 379-389.

Jorquera, B., Pugin, E., Garrido, O., Goicoechea, O. \& R., Formas. 1981. Procedimiento de desarrollo en dos especies del genero Rhinoderma. Medio Ambiente 5(1-2): 58-71.

Loft, B. 1974. Physiology of the Amphibia. Ed. Academic Press,inc. Vol.2, New York.

Mayhew, W. \& S., Wright. 1970. Seasonal changes in testicular histology of three species of the lizard genus Uma. J. Morphol. 130: 163-186.

Morton, M.L. 1981. Seasonal changes in total body lipid and liver weight in the Yosemite toad. Copeia 1981: 234-238.

Ortiz, J.C. 1981. Révision taxinomique et biologie des Liolaemus du groupe nigromaculatus (Squamata - Iguanidae). Thèse de Doctorat d'état ès Sciences Naturelles. Université PARIS VII, France: 438pp.

Penna, M \& R., Solis. 1992. Anillos de crecimiento oseo y actividad reproductiva en machos de Pleurodema thaul (Anura-Amphibia). Rev. Chil. Anat. 10(1):51 (1991).

Ramirez, M.P. 1995. Reproductive and fat body cycles of the oviparous lizard Liolaemua bitaeniatus (Sauria: Tropiduridae). J. Herpetol. 29: 256-260.

Rastogi, R.K., Iela, L., Saxena, P.K. \& G., Chieffi. 1976. The control of spermatogenesis in the Green frog, Rana esculenta. J. Exp. Zool. 196: 151-166. 
Rastogi, R.K., Iela, L., Di Meglio, M., Di Matteo, L., Minucci, S. \& I., Izzo-Vitiello. 1983a. Initiation and kinetic profiles of spermatogenesis in the frog, Rana esculenta (Amphibia). J. Zool. (London) 201: 515-525.

Rastogi, R.K., Izzo-Vitiello, I., Di Meglio, M., Di Matteo, L., Franzese, R., Di Costanzo, M.G., Minucci, S., Iela, L. \& G., Chieffi. 1983b. Ovarian activity and reproduction in the frog, Rana esculenta. J. Zool. (London): 200: 233-247.

Ritke, M. \& Ch., Lessman. 1994. Longitudinal study of ovarian dynamics in female Gray treefrogs (Hyla chrysoscelis). Copeia 1994: 1014-1022.

Saidapur, S.K. \& B., Hoque. 1996. Long - term effect of ovariectomy on abdominal fat body and body masses in the frog Rana tigrina during the recrudescent phase. J. Herpetol. 30: 70-73.

Solis, R. 1994. Factores moduladores de las interacciones sociales acústicas de Pleurodema thaul. $\mathrm{Ph}$. D. Dissertation, Universidad de Chile, Chile: 76pp.

Van Beurden, E. 1979. Gamete development in relation to season, moisture, energy reserve, and size in the Australian water - holding frog Cyclorana platycephalus. Herpetologica 35: 370-374.

Verrel, P.A., Halliday, T.R. \& M.L., Griffiths. 1986. The annual reproductive cycle of the smooth newt (Triturus vulgaris) in England. J. Zool. (London) 210a: 101-119.

Victoriano, P., J. C. Ortiz, L. Troncoso \& R. Galleguillos. 1995. Allozyme variation in populations of Pleurodema thaul (Anura; Leptodactylidae). Comp. Biochem. Physiol.B: 487-492

Wake, M.H. 1995. The spermatogenic cycle of Dermophis mexicanus (Amphibia: Gymnophiona). J Herpetol. 29: 119-122.

Wilhelm, O. 1927. La Rhinoderma darwinii D. \& B. Bol. Soc. Biol. Concepción 1(1-2): 30-31.

Zar, J.H. 1996. Biostatistical Analysis. Third edition. Prentice Hall, Inc. Engelwood Cliffs, N.J.

Received: January 3, 2000. Accepted: May 15, 2001. 